\title{
The Eemian interglacial in Sweden, and comparison with Finland
}

\author{
Ann-Marie Robertsson ${ }^{1}$ \\ 1 Department of Quaternary Research, Stockholm University, S-10691 STOCKHOLM, \\ Sweden
}

Manuscript accepted in revised form: 5 April 2000

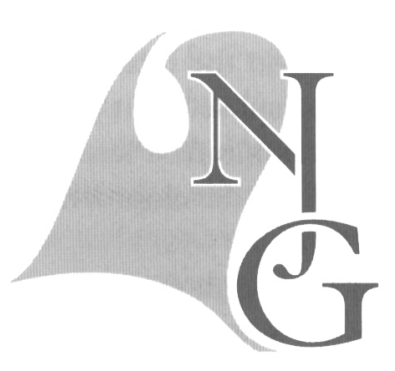

\begin{abstract}
The current status of knowledge concerning the Eemian interglacial in Sweden is surveyed, and comparisons are made with northern and western Finland. The course of shore displacement is fragmentarily known for Sweden, since brackish-marine sediments have been identified, on the basis of diatom analysis, at only few sites. In Finland, on the other hand, a shoredisplacement curve has been constructed for the Eemian Baltic Sea in Ostrobothnia, central western Finland.

The vegetation history is summarised for the southernmost part of Sweden, and can be correlated with that documented in Denmark. For the central part of Sweden, information is sparse, but the composition of the forests has been outlined for most of the interglacial, although information on regional pollen assemblage zones E3 and E4 (early-temperate substage) are mainly missing. A more complete picture of the interglacial vegetational history is known from Ostrobothnia in Finland. The thermophilous indicators Viscum, Ilex, Hedera and Osmunda grew far North during the Eemian. Corylus and Carpinus expanded much further to the North than during the Holocene. In Swedish and Finnish Lapland, the vegetation history is similar except that Larix was common in Finland during the Eemian, but its presence has so far not been confirmed in Sweden.

Eemian deposits relocated during the Weichselian glaciation contain pollen and diatoms that can be used for reconstruction of the Eemian environment. No clear indication of a rapid climatic deterioration during the Eemian has been found so far in either Swedish or Finnish sequences.
\end{abstract}

Key words: Eemian, Finland, rebedded pollen, relocated deposits, shore displacement, Sweden, vegetation history

\section{Introduction}

Deposits thought to represent the entire Eemian interglacial have so far been found at only a few sites in Sweden (Fig. 1). Our knowledge of climate change, vegetation history and shore displacement in Sweden during the Eemian is thus fragmentary. The main reason is that the ice sheet tectonised, dislocated and eroded interglacial deposits during the first Weichselian stadial. The erosional effect was, however, generally strong in several parts of the country. In some areas, such as Norrbotten in northernmost Sweden, the ice was partly cold-based and it affected the morphology of the landscape to a very limited extent (Lagerbäck, 1988; Kleman, 1994; Hättestrand, 1997). In Norrbotten, many sites have been found that con- tain organic-bearing sediments accumulated during at least two (Early) Weichselian interstadials (Nordkalott Project, Hirvas et al., 1988; Lagerbäck \& Robertsson, 1988). These sequences do, however, not include Eemian deposits. There is, sofar, only one site - Leveäniemi - known to represent a more or less complete interglacial succession correlated with the Eemian (Lundqvist, 1971; Robertsson, 1997). The sites Kätkijärvet and Seitevare in Norrbotten have also been suggested to contain Eemian sediments (Robertsson \& Rodhe, 1988; Robertsson, 1991). The correlation of these interglacial sequences with Eemian sites in NW Europe is problematic because of the great distance. The flora was much less diverse in northern Scandinavia, which means that thermophilous elements, for example mixed oak forest (QM), 


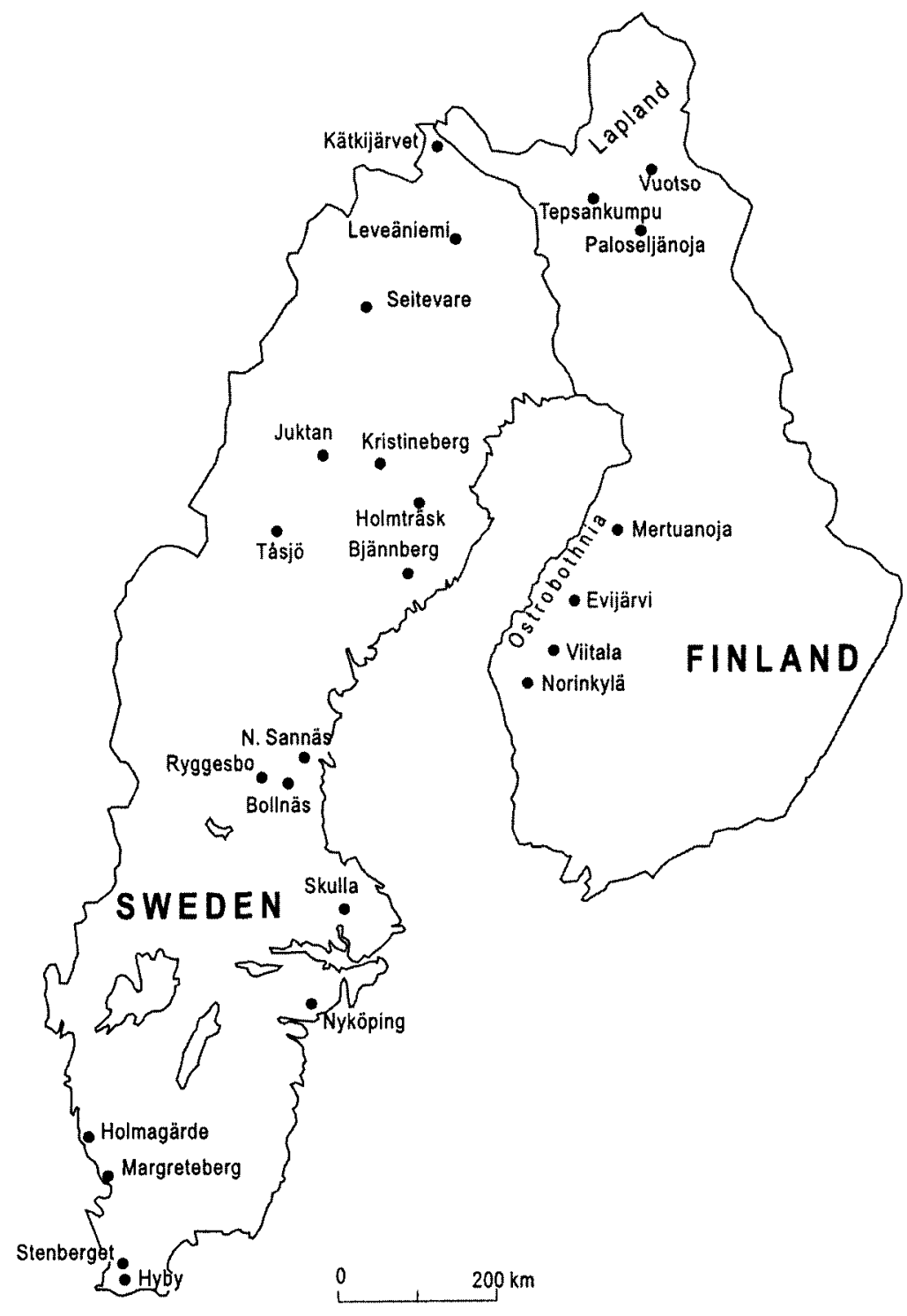

Fig. 1. Survey map of Sweden and Finland showing sites and areas discussed in the text.

Carpinus, Viscum, Hedera and Ilex, are missing from the pollen flora. Some of these plants are, however, present in the pollen flora identified at Eemian sites in southern Sweden (Berglund \& Lagerlund, 1981; Påsse, 1992).

\section{Redeposited interglacial (Eemian) pollen flora}

The presence of interglacial (possibly Eemian) deposits has been shown by analysis of pollen and spores occurring as redeposited microfossils in tills and sediment clasts in tills deposited during the Weichselian (Miller, 1977; Lagerbäck \& Robertsson, 1988; Lundqvist \& Miller, 1992; Robertsson \& García Ambrosiani, 1992). During mapping of Quaternary deposits in northern Sweden, the lithostratigraphy has been documented in several hundred machine-excavated pits (Hirvas et al., 1988; Eklund et a1., 1991). Fine-grained mineral sediments, including tills, have been analysed for their content of pollen and spores. In the many samples analysed, a certain pattern can be seen in the presence and composition of the pollen flora. An interglacial 'signature' has been found in samples taken from sediments and tills covered by at least two different till beds. In contrast, more superficial sediment and till layers are usually void of pollen, or the pollen flora has an 'interstadial' composition dominated by herbs and shrubs, and with birch as the only tree species represented (Robertsson \& Lagerbäck, 1988; Lundqvist \& Miller, 1992).

\section{Eemian shoreline displacement}

Along the Swedish east coast, the sites Bollnäs, $\mathrm{N}$. Sannäs, Skulla and Nyköping have been shown to contain brackish-marine diatoms in sediments of supposedly Eemian age (Erikson, 1912; Halden, 1915; Miller \& Persson, 1973; Robertsson \& García Ambrosiani, 1992; Robertsson et al., 1997). 
Bollnäs occurs at the highest altitude (approx. 88 $\mathrm{m}$ ) of the sites studied. The bulk sample, which contained brackish and marine diatoms, has not been analysed for its pollen content, so it is unknown which Eemian regional pollen zone the sediments represent. The highest Holocene marine limit in the area was formed by the Litorina Sea, which reached approx. $120 \mathrm{~m}$ above present sea level.

A clay containing brackish marine diatoms at $\mathrm{N}$. Sannäs is situated approx. $25 \mathrm{~m}$ above present sea level and the composition of the pollen flora indicates the later half of the interglacial, since Picea occurs at $17 \%$ of total land pollen. At this low altitude, brackish-marine conditions may have prevailed for a long part of the Eemian interglacial.

Skulla is situated approx. $55 \mathrm{~m}$ above sea level. The slightly brackish diatom flora is suggested to represent the beginning of a transgressive phase or isolation from the sea (Robertsson \& García Ambrosiani, 1992). According to pollen analyses, the till-covered clay was originally deposited before the spread of spruce and hornbeam (Fig. 2), i.e., during regional pollen assemblage zone (PAZ) E4. The Holocene marine (Litorina) shoreline limit in the area is at 70-75 $\mathrm{m}$ above sea level.

The clay found redeposited in glacial sand in Nyköping was deposited under marine conditions (Miller \& Persson, 1973). The composition of the diatom flora suggests higher salinity than during the Holocene, whilst the pollen flora indicates deposition before the immigration of Picea. Very few pollen grains, mainly including Tilia, were noted, however.
This sparse information on the Eemian Sea and shoreline displacement in Sweden can be compared with Finland, where the stratigraphy at many sites has been found to represent various stages of the Eemian sea (Fig. 1b). During an early phase of the interglacial, the Baltic was a fresh-water basin, comparable to the Holocene Ancylus Lake, as indicated by diatom analyses from the Norinkylä, Viitala and Mertuanoja sites in Ostrobothnia (Grönlund, 1991a,b; Eriksson et al., 1999). The existence of a connection between the Baltic basin and the White Sea in the North has been confirmed by finds of Arctic marine silicoflagellates in the marine Eemian sediments at Ostrobothnia (Grönlund, 1991a,b). Based on the results from a number of sites, it appeared even possible to reconstruct a shore-displacement curve for the Eemian Sea in Ostrobothnia (Forsström et al., 1988). The highest Eemian marine shoreline reached over $20 \mathrm{~m}$ above the Holocene Litorina Sea level in the same area (Saarnisto \& Salonen, 1995).

The type site for the Eemian stage in Ostrobothnia is Evijärvi (Eriksson et al., 1980; Donner, 1995) and in Finnish Lapland it is Tepsankumpu (Saarnisto et al., 1999).

\section{Eemian vegetation history}

\section{The northernmost part of Sweden and Finland}

Analysis of pollen, macrofossils and insect remains from the organic sequence at Leveäniemi has given the following (most complete) picture of the vegeta-

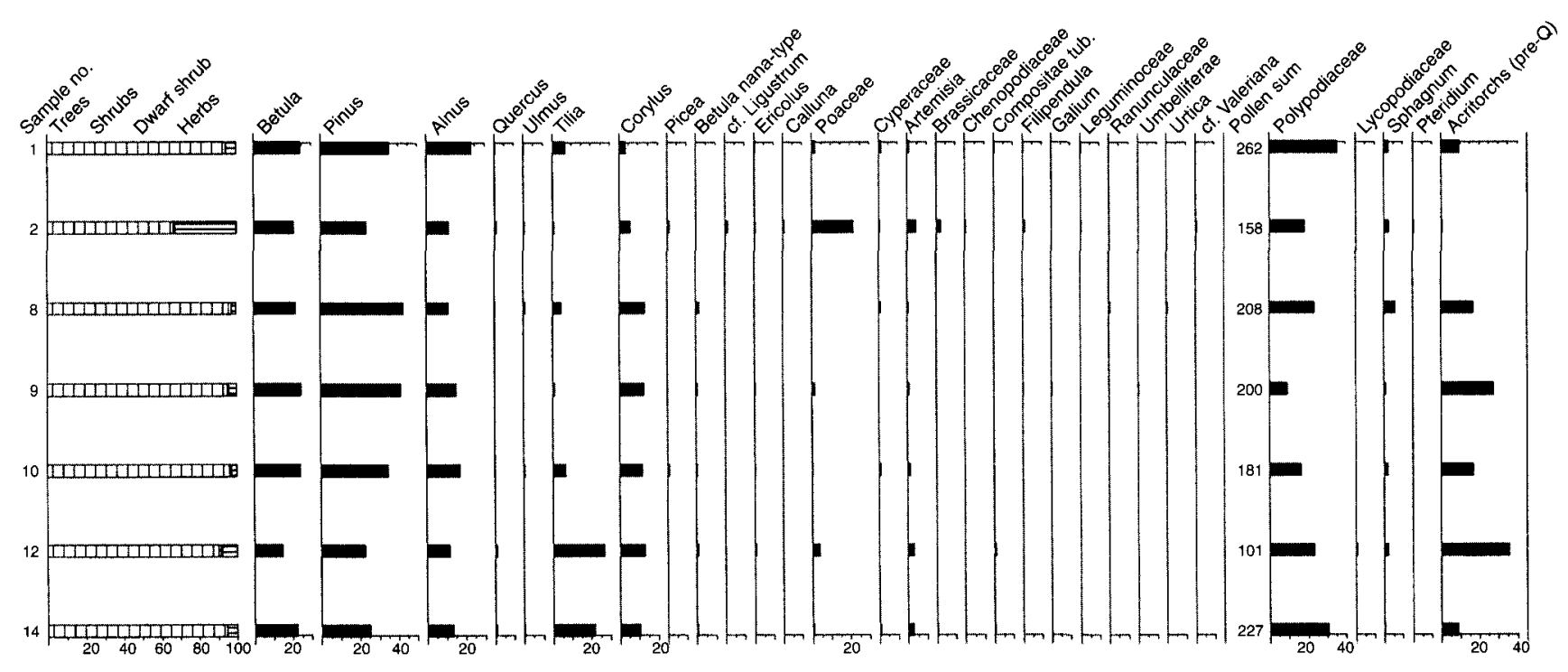

Fig. 2. Pollen spectra from a redeposited supposedly Eemian clay at Skulla, southern Sweden. A brackish-water diatom flora was identified in sample no. 2 (cf. Robertsson \& Garcia Ambrosiani, 1992). 


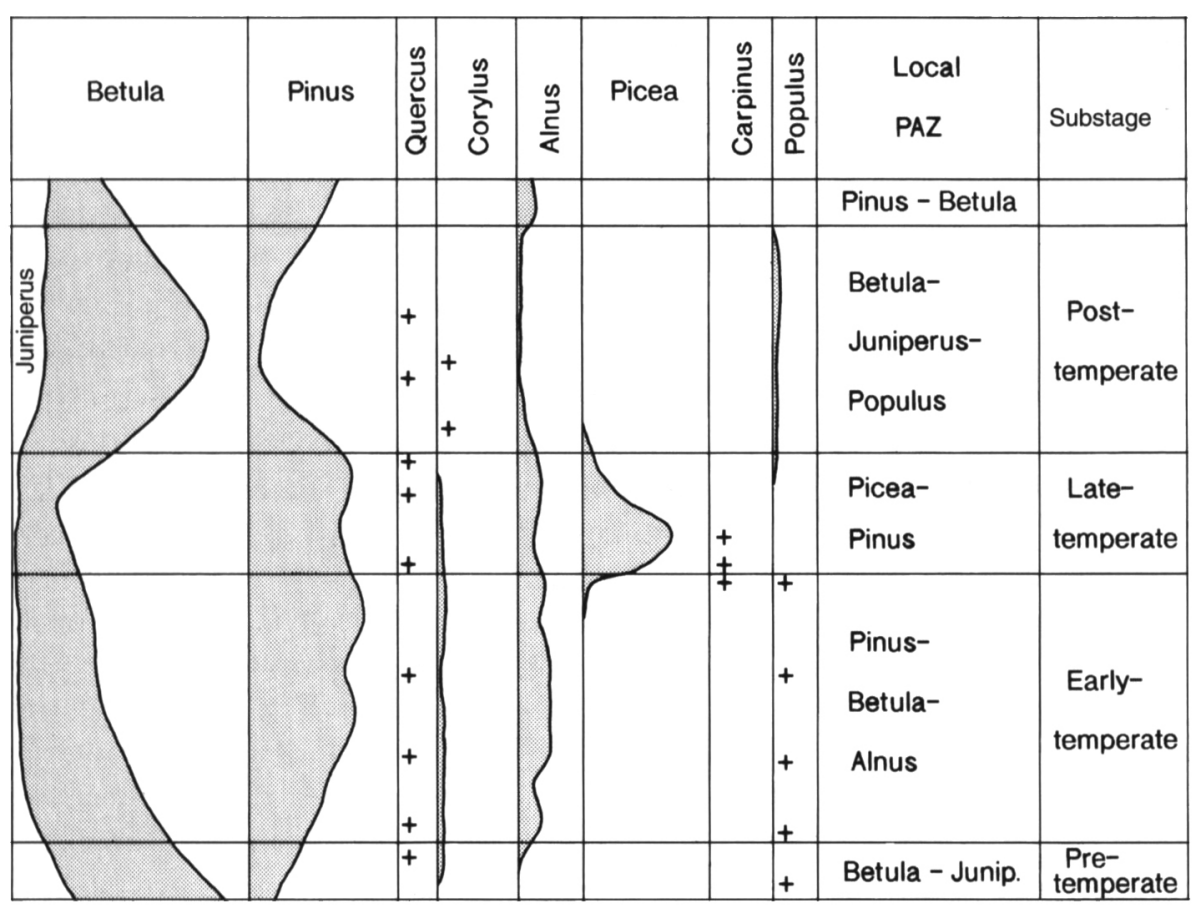

Fig. 3. Simplified pollen diagram for Leveäniemi, northernmost Sweden (after Robertsson, 1997).

tional history in this northern area (Fig. 3) (cf. Lundqvist ,1971; Robertsson, 1997).

The pre-temperate substage is characterised by the presence of light-demanding herbs and shrubs, and open birch forest (Betula/funiperus PAZ). The temperature seems to have risen rather rapidly during this phase (PAZ E1-E2), indicated by the presence of water plants that need a mean July temperature above $+13^{\circ} \mathrm{C}$ (Nuphar, Nymphaea, Typha).

The early-temperate substage began with the spread of Pinus and Alnus. The northward migration of Corylus is reflected by some long-distance-transported pollen grains in the Pinus/Betula/Alnus PAZ. The thermophilous QM components never reached this far North, but some single long-distance pollen grains have been noted.

The late-temperate substage is characterised by the spread of Picea and high frequency of Pinus, together with the appearance of long-distance-transported Carpinus pollen.

During the post-temperate substage, the forests seem to have been more open, as Betula and Populus occur frequently. Funiperus and Salix also increased markedly in the Betula/funiperus/Populus PAZ (Robertsson, 1997). The changes in the aquatic environment have been documented by diatom studies (Miller, 1971). The succession of diatoms suggests eutrophic, alkaline conditions at the beginning, followed by an oligotrophic/dystrophic phase with acidic water during peat formation. At the end of the interglacial, the $\mathrm{pH}$ rose, which is interpreted as reflecting input of seasonal meltwater from surrounding areas.
A thin, compressed peat layer at Seitevare has been suggested to have been deposited during the later part of the Eemian, when the vegetation was composed of a mixed forest with pine, birch, alder and spruce. The diatom flora was dominated by acidophilous taxa. The most northern site, Kätkijärvet, is situated nowadays in an area above the forest limit. During the Eemian, the area was also mostly covered by shrub and herb communities, maybe with some sparse birch and pine forest. Moreover, spruce probably grew closer to this area than during the Holocene (Robertsson, 1991). The vegetation history reflected at Leveäniemi can be correlated with the many interglacial sequences in northern Finland (Finnish Lapland) (Hirvas, 1991). The most complete successions have been found at Tepsankumpu (Hirvas, 1983; Saarnisto et al., 1999), representing the beginning and middle part of the interglacial, and Paloseljänoja (Hirvas, 1991), where the middle and later parts have been preserved. A major difference is that Larix was an important component of the Eemian coniferous forests in northern Finland (Hirvas et al., 1981). At Vuotso, even a large trunk of Larix was found together with cones of Picea and Pinus. The occurrence of Larix pollen suggests that this tree was rather common and probably immigrated together with Picea (Forsström, 1990).

The absence of Larix in Sweden is by no means proven by the lack of its pollen in the Leveäniemi pollen flora, since Larix is a poor pollen producer, and the pollen is not well dispersed. For comparison it should be mentioned that Larix is not considered to 
have been growing naturally in Sweden during the Holocene. Cones and wood of Larix sibirica were found recently in the Scandinavian Mountains and dated at approx. 8700-7500 BP (Kullman, 1998a).

\section{Central Sweden and Ostrobothnia in Finland}

Very few organic deposits have, sofar, been found in central Sweden. They are interpreted as having accumulated during the Eemian (Fig. 1). Apart from redeposited pollen identified in mineral layers (sediments including till), only the sites of N. Sannäs, Bollnäs and Ryggesbo seem to include sediments deposited during both the beginning and the later part of the Eemian. Since the early-temperate substage is probably missing, the correlation of the sites with the Eemian stage is not undoubtedly proven.

The start of the interglacial is represented at $\mathrm{N}$. Sannäs and Bollnäs (Fig. 4). Quercus and Corylus reach approx. $5 \%$ and $15 \%$, respectively, of total land pollen, while Tilia and Ulmus are only represented by single pollen grains. Single spores of a thermophilous fern, Osmunda, were identified at N. Sannäs. Fine silt with some macroscopic plant remains accumulated at Ryggesbo during the later half of the Eemian, according to the tree-pollen assemblage, since Picea occurs at values above $10 \%$ of the tree pollen sum (Lundqvist, 1963).

Several sites containing Eemian sediments have been identified at Ostrobothnia in Finland (Nenonen, 1995). A comprehensive review of the vegetational history, based on pollen stratigraphy, has been presented by Eriksson (1993) in a scheme with five regional PAZs (I-V) correlated to the pre-temperate (I), early-temperate (II and III), late-temperate (IV) and post-temperate (V) substages. Eriksson concluded that Corylus and Carpinus (single trees) grew at Ostrobothnia during this time, and that Quercus and $U l$ mus also had a more northerly distribution in Finland than during the Holocene. Even thermophilous indicators, such as Ilex, Viscum and possibly Hedera, were present in southern Ostrobothnia during the Eemian interglacial (Eriksson, 1993). Spores of Osmunda occur in sediments formed during the later part of the interglacial (Eriksson et al., 1999).

\section{Southernmost Sweden}

The most complete Eemian sequence, although not in primary position, has been found at Holmagärde on the Swedish West coast (Påsse, 1992). The vegetation succession (Fig. 5) can be correlated clearly with Hollerup in Denmark (Andersen, 1975), but most of the regional pollen assemblage zone E2, the entire zones E3 and E7 are missing at Holmagärde (Påsse, 1992; Fig. 5). Zone E4, dominated by Corylus, Quercus and Alnus, is clearly represented, as well as the following Carpinus/Picea zone (E5 and beginning of E6).

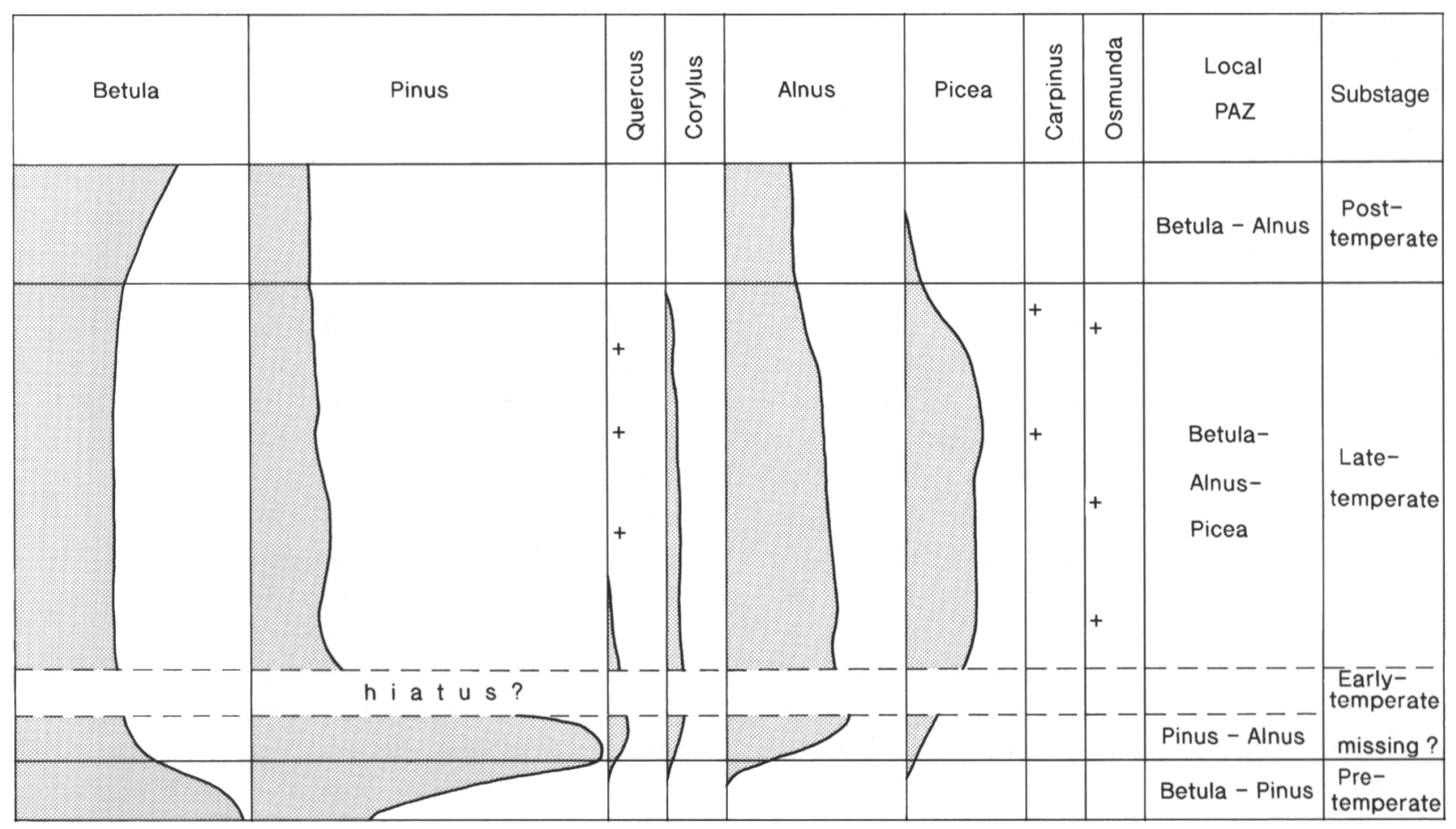

Fig. 4. Generalised pollen diagram for the Eemian interglacial deposits at Bollnäs, central Sweden (after Robertsson et al., 1997). 


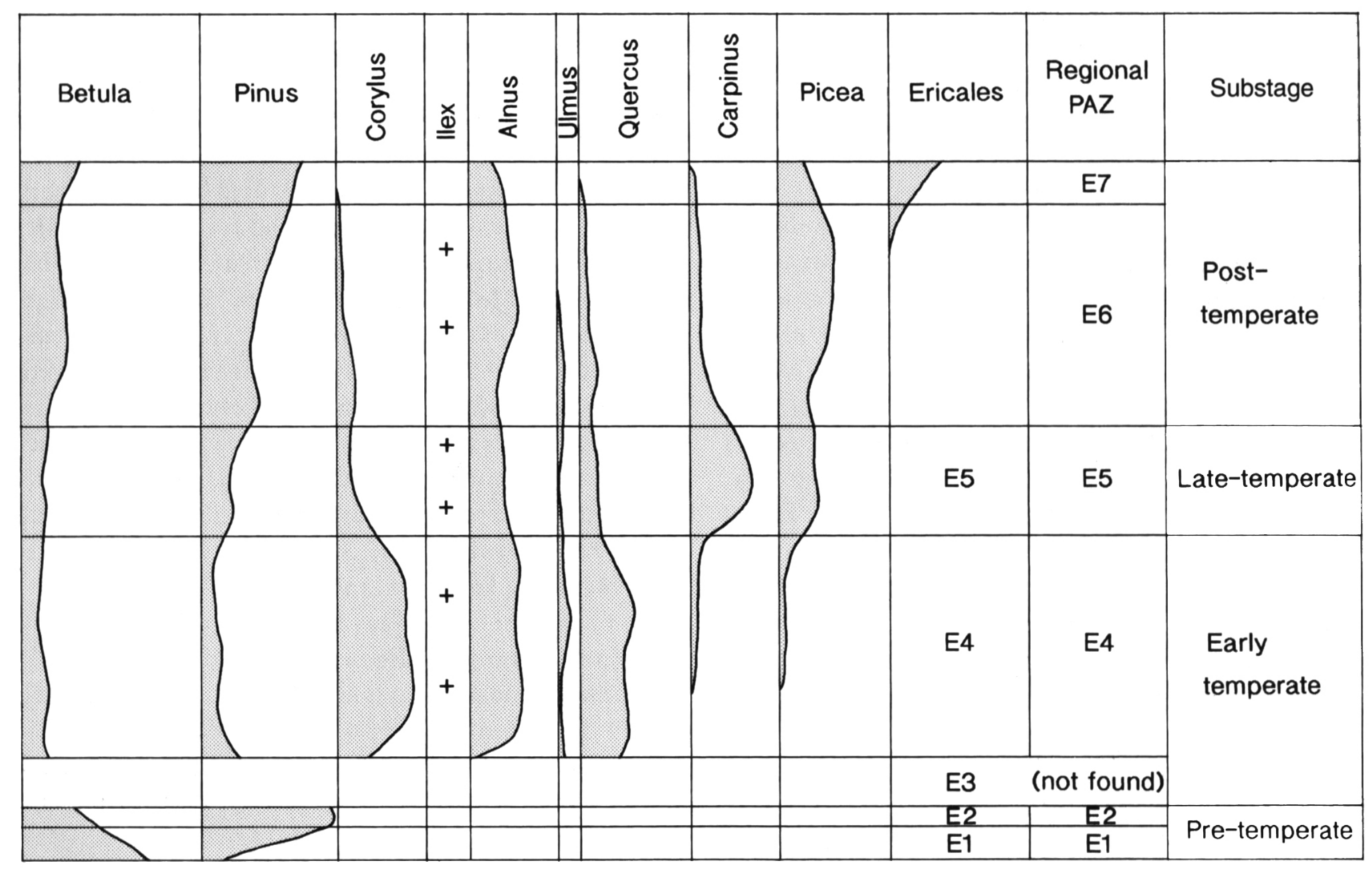

Fig. 5. Generalised pollen diagram for Eemian deposits in southern Sweden (data from Berglund \& Lagerlund, 1981; Påsse et al., 1988; and Påsse, 1992).

The sediments accumulated in a marine (E1), shallow-marine (E4, E5), and fluvial (E6) environment. The sequence is underlain by Saalian glaciomarine clays containing shallow arctic and boreal-arctic foraminifers (Klingberg, in: Påsse, 1992).

At Margreteberg, thin layers of peat, formed in a fluvial environment, have been correlated with the end of the Eemian stage. The regional PAZs E6 and E7 are represented by a Picea/Pinus/Alnus and an Ericales/Picea (/Sphagnum) zone, respectively (Robertsson, in: Påsse et al., 1988). Zones E4 and E5 are recorded as redeposited pollen spectra. The stratigraphy at Margreteberg includes late Saalian marine clay, as well as Early Weichselian periglacial solifluction sediments and an early Middle (?) Weichselian glaciolacustrine deposit ('till'). Besides pollen analysis, several types of evidence have been investigated, including wood remains, foraminifers, diatoms and molluscs (Påsse et al., 1988). The latter indicate brackish-marine conditions during late Saalian to early Eemian.

Stenberget is the most southerly locality with in situ organic lake and mire deposits (clay gyttja, peat and dy) correlated with the Eemian (Berglund \& Lagerlund, 1981). The stratigraphy at this site con- tains an hiatus including zones E3, E4 and E5, howev$\mathrm{er}$, and is estimated to span $8000-9000$ years. The very beginning of the interglacial was characterised by pioneer plants forming a Betula/Gramineae/Artemisia PAZ correlated to zone E1, followed by a Pinus PAZ correlated with zone E2. The end of the Eemian is represented by an Alnus/Picea/Gramineae PAZ (E6 and part of E7), a Picea/Pinus/Betula PAZ (E7) and a Betula/Pinus/Gramineae/Cyperaceae PAZ (E7). Only the preand post-temperate substages are thus represented, and the correlation to the Eemian is not totally proven.

\section{Summary}

\section{Shoreline displacement}

Until today very little is known about land uplift and shore displacement in Sweden during the Eemian. At a few sites, single marine or brackish diatom spectra have been noted, showing that the sediments (clays) were originally deposited in a marine environment. The deposits have, however, been relocated and found in secondary position at rather low altitudes above present sea level, except at Bollnäs, at $88 \mathrm{~m}$ above present sea level. 
In Finland, the evidence is much more complete and, on basis of the regional lithostratigraphy and results of diatom analyses, a regional shore-displacement curve has even been constructed for Ostrobothnia in western central Finland. A fresh-water stage has been identified to have preceded the Eemian marine transgression, which probably began already at the end of the regional Betula PAZ. Fennoscandia was most probably an island when the Baltic Sea was connected with the White Sea during part of the Eemian, but the duration of this connection is under discussion after recent data from NW Russia, Karelia and Denmark. The Eemian sea level reached a maximum of at least $20 \mathrm{~m}$ higher than the Holocene Litorina Sea in western central Finland.

\section{Vegetation history}

The regional PAZs for Denmark, Scandinavia and Estonia have been compiled in Table 1. In addition, simplified pollen diagrams are presented to illustrate the spread and occurrence of the most important trees and other plants in the region during the Eemian (Figs. 3-5).

The vegetation history of the Eemian in Southern Sweden can generally be compared with Denmark, as illustrated by the diagram from Holmagärde and Stenberget (Fig. 5: simplified after Berglund \& Lagerlund, 1981; and after Påsse, 1992). Sediments representing the beginning and end of the interglacial are missing at Holmagärde, but data from Stenberget have been added, since zones E1, E2, E6 and E7 are thought to be represented there. The most prominent differences observed can be explained partly by local factors (soils, topography, microclimate, etc), sedimentary environment and type of deposit, and partly by the varied immigration patterns of trees. It should also be stressed that the Swedish material consists of only three pollen diagrams, two of which (Margreteberg and Stenberget) are fragmentary. The main discrepancies observed are:

- Taxus has so far not been identified at the Swedish

Table 1. Compilation of regional Eemian pollen assemblage zones distinguished in Denmark (Andersen, 1975), southwestern Norway at Fjösanger (Mangerud et al., 1981), northernmost Sweden at Leveäniemi (Lundqvist, 1971; Robertsson, 1971, 1997), northern and central Finland (Hirvas, 1991; Eriksson, 1993) and Estonia (Liivrand, 1991).

$\mathrm{Te}=$ Tesankumpu and $\mathrm{Pa}=$ Paloseljänoja.

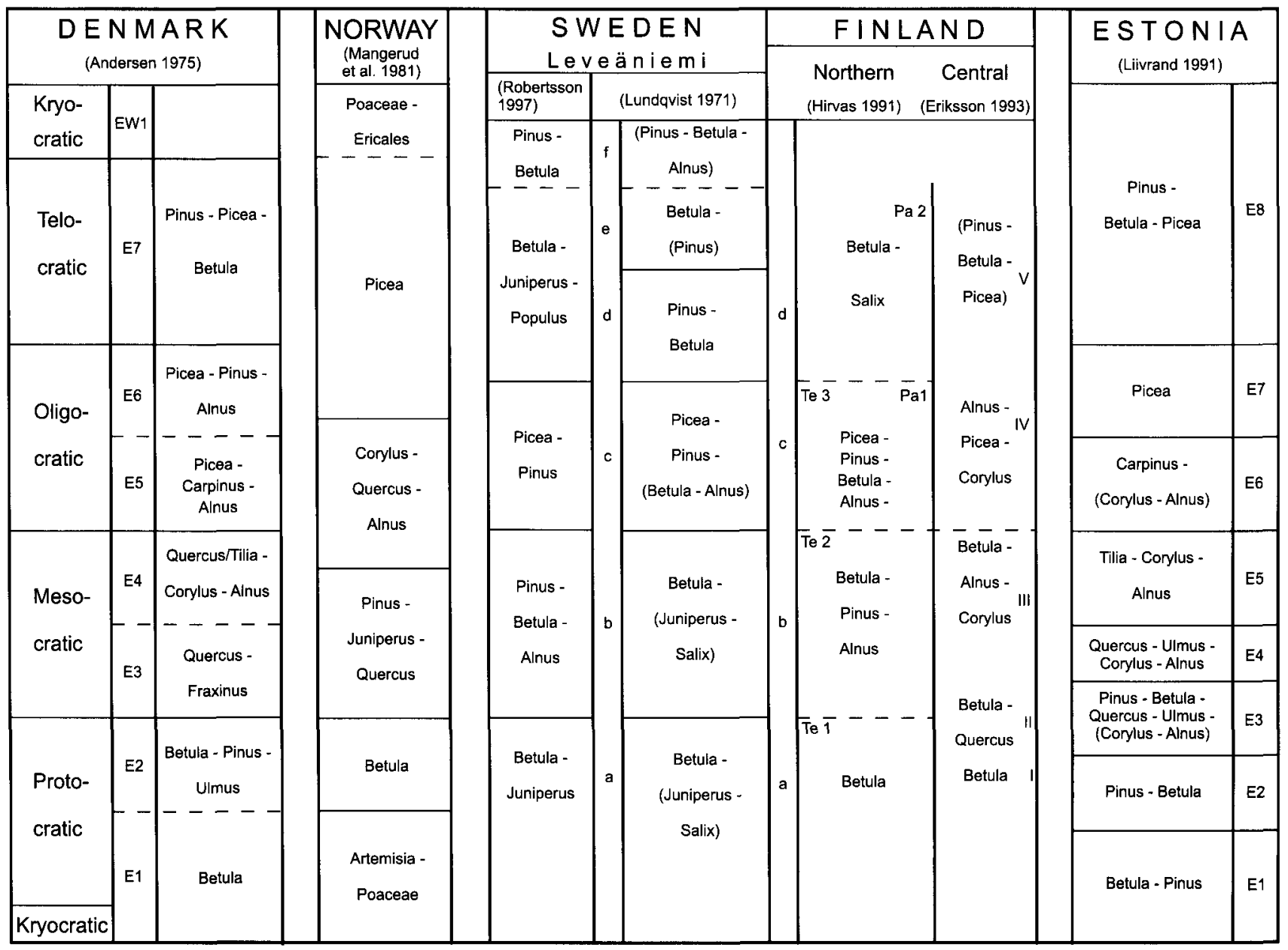


sites,

- the values for Fraxinus in Sweden are lower than in Denmark,

- a thermophilous taxon, Ilex, has been noted in the Holmagärde sequence, but not Viscum nor Hedera.

These differences can, however, be explained by the fact that zone E4 at Holmagärde is represented in marine sediments, which commonly give a more regional pollen signal. Plants that produce little pollen, such as Viscum and Hedera, are rarely found in the marine pollen spectra.

There are unfortunately areas lacking almost any information about the Eemian interglacial: a large area in the southernmost part of Sweden, and an area in the central part of the country. The sites within these areas contain only fragmentary sediments found relocated and embedded in Weichselian deposits (glaciofluvial sediments or till beds). The pollen spectra from Skulla (Fig. 2), however, show that thermophilous trees (Corylus, Quercus, Tilia) grew in this part of Sweden during the Eemian - if the sediments are indeed of Eemian age, which is not without doubt.

The generalised diagram from Bollnäs (Fig. 4) illustrates the vegetation succession during the very beginning of the Eemian, and the main part of the rest of the interglacial, except the early-temperate substage, which is probably missing from the sequence studied.

In the northernmost part of Sweden, the forests were dominated by birch, pine, alder and spruce. Thermophilous trees were represented, mainly by long-distance-transported pollen grains (Fig. 3). It was assumed until now that Corylus and Quercus, as well as other broad-leaved trees, immigrated further to the North during this interglacial than during the Holocene. The Holocene forest history in northern Sweden has, however, essentially been revised (Kullman, 1998b). New finds of Alnus glutinosa, Tilia cordata and Betula pendula (macroscopic remains) have been made far beyond their present-day distributions. This implies that the difference between the distribution during the Eemian and the early Holocene was possibly not as great as thought hitherto. It is interesting to note that even the Carpinus zone can be recognised in the Leveäniemi diagram (Fig. 3) by single long-distance-transported pollen grains.

\section{Climate change}

On the basis of the analyses of micro- and macrofossils, it is concluded that the Eemian climate in Sweden and surrounding areas showed a rapid warming even during the pre-temperate substage. Thermophilous water plants spread far to the North, indicating a mean summer temperature around $13^{\circ} \mathrm{C}$ at
Leveäniemi early in the interglacial. The coleopteran assemblage has given the same indication.

Sofar, the biostratigraphical results have not given any clear evidence for any longer-term climatic deterioration during the Eemian (Robertsson, 1997; Saarnisto et al., 1999). Since connections with the Arctic Ocean via the White Sea and the Atlantic Ocean via the straits in the southern Baltic basin shifted during the Eemian, this must have influenced the climate and thus both the aquatic and terrestrial vegetation.

\section{Acknowledgements}

Urve Miller and Jan Lundqvist kindly read the manuscript and gave valuable comments. Laszlo Madarasz made the drawings. The study was granted by the Swedish Natural Science Research Council.

\section{References}

Andersen, S.Th., 1975. The Eemian freshwater deposit at Egernsund, South Jylland, and the Eemian landscape development in Denmark. Danmarks Geologiske Undersøgelse Årbog 1974: 4970.

Berglund, B.E. \& Lagerlund, E., 1981. Eemian and Weichselian stratigraphy in South Sweden. Boreas 10: 323-362.

Donner, J., 1995. The Quaternary history of Scandinavia. World and regional geology 7. Cambridge University Press: 200 pp.

Eklund, A., Hellström, G., Rodhe, L., Sundh, M., Svedlund, J.-O. \& Wiberg, B., 1991. Till stratigraphic studies in Västerbotten, northern Sweden - some preliminary results. Striae 34: 99-102.

Erikson, B., 1912. En submorän fossilförande aflagring vid Bollnäs i Hälsingland. Geologiska Föreningens i Stockholm Förhandlingar 34: 500-541.

Eriksson, B., 1993. The Eemian pollen stratigraphy and vegetational history of Ostrobothnia, Finland. Geological Survey of Finland Bulletin 372: $36 \mathrm{pp}$.

Eriksson, B., Grönlund, T. \& Kujansuu, R., 1980. An interglacial deposit at Evijärvi in the Pohjanmaa region, Finland [in Finnish with English summary]. Geologi 32: 65-71.

Eriksson, B., Grönlund, T. \& Uutela, A., 1999. Biostratigraphy of Eemian sediments at Mertuanoja, Pohjanmaa (Ostrobothnia), western Finland. Boreas 28: 274-291.

Forsström, L., 1990. Occurrence of larch (Larix) in Fennoscandia during the Eemian interglacial and Brörup interstadial according to pollen analytical data. Boreas 19:241-248.

Forsström, L., Aalto, M., Eronen, M. \& Grönlund, T., 1988. Stratigraphic evidence for Eemian crustal movements and relative sealevel changes in Eastern Fennoscandia. Paleogeography Paleoclimatology Palaeoecology 68: 317-335.

Grönlund, T., 1991a. New corings from Eemian interglacial marine deposits in Ostrobothnia, Finland. Geological Survey of Finland Bulletin 352: 23 pp.

Grönlund, T., 1991b. The diatom stratigraphy of the Eemian Baltic Sea on the basis of sediment discoveries in Ostrobothnia, Finland. Geological Survey of Finland Report of Investigation 102: $26 \mathrm{pp}$.

Halden, B. E:son, 1915. Det interglaciala Bollnäsfyndets stratigrafi. Geologiska Föreningens i Stockholm Förhandlingar 37: 452-479.

Hättestrand, C. 1997. The glacial geomorphology of central and northern Sweden. Geological Survey of Sweden Research Pa- 
pers Ca 85: 47 pp.

Hirvas, H., 1983. Correlation problems of interglacial deposits in Finnish Lapland. IGCP Project 73/1/24 Report 9 (Paris): 129 139.

Hirvas, H., 1991. Pleistocene stratigraphy of Finnish Lapland. Geological Survey of Finland Bulletin 354: 123 pp.

Hirvas, H., Korpela, K. \& Kujansuu, R., 1981. Weichselian in Finland before 15.000 B.P. Boreas 10: 423-431.

Hirvas, H., Lagerbäck, R., Mäkinen, K., Nenonen, K., Olsen, L., Rodhe, L. \& Thoresen, M., 1988. The Nordkalott Project: studies of Quaternary geology in northern Fennoscandia. Boreas 17: 431-437.

Kleman, J., 1994. Preservation of landforms under ice sheets and ice caps. Geomorphology 9: 19-32.

Kullman, L., 1998a. Palaeoecological, biogeographical and palaeoclimatological implications of early Holocene immigration of Larix sibirica Ledeb. into the Scandes Mountains, Sweden. Global Ecology and Biogeography Letters 7: 181-188.

Kuliman, L., 1998b. The occurrence of thermophilous trees in the Scandes Mountains during the early Holocene: evidence for a diverse tree flora from macroscopic remains. Journal of Ecology 86: $421-428$.

Lagerbäck, R., 1988. The Veiki moraines in northern Sweden widespread evidence of an Early Weichselian deglaciation. Boreas 17: 469-486.

Lagerbäck, R. \& Robertsson, A.-M., 1988. Kettle holes - stratigraphical archives for Weichselian geology and palaeoenvironment in northernmost Sweden. Boreas 17:439-468.

Liivrand, E., 1991. Biostratigraphy of the Pleistocene deposits in Estonia and correlations in the Baltic region. Ph.D. thesis Stockholm University; Department of Quaternary Research Report 19: 114 pp.

Lundqvist, G., 1963. Beskrivning till jordartskarta över Gävleborgs län. Sveriges Geologiska Undersökning 42: $181 \mathrm{pp}$.

Lundqvist, J. (ed.), 1971. The interglacial deposit at the Leveäniemi mine, Svappavaara, Swedish Lapland. Sveriges Geologiska Undersökning C 658: 163 pp.

Lundqvist, J. \& Miller, U., 1992. Weichselian stratigraphy and glaciations in the Tåsjö-Hoting area, central Sweden. Sveriges Geologiska Undersökning Research Papers C 826: 35 pp.

Mangerud, J., Sönstegaard, E., Sejrup, H.P. \& Haldorsen, S., 1981. A continuous Eemian - Early Weichselian sequence containing pollen and marine fossils at Fjösanger, western Norway. Boreas 10: 137-208.

Miller, U., 1971. Diatom floras in the sediments at Leveäniemi. In: Lundqvist, J. (ed.): The interglacial deposit at the Leveäniemi mine, Svappavaara, Swedish Lapland. Sveriges Geologiska Undersökning C 658: 104-163.

Miller, U,. 1977. Pleistocene deposits of the Alnarp Valley, southern Sweden - Microfossils and their stratigraphical application. Ph.D. thesis University of Lund: $125 \mathrm{pp}$.

Miller, U. \& Persson, Ch., 1973. A lump of clay embedded in glacial intermorainic sand. Geologiska Föreningens i Stockholm Förhandlingar 95: 342-346.

Nenonen, K., 1995. Pleistocene stratigraphy and reference sections in southern and western Finland. Geological Survey of Finland, Regional Office for Mid-Finland, Dissertation: $94 \mathrm{pp}$.

Påsse, T., 1992. A Late Pleistocene sequence at Holmagärde, south-western Sweden. Geological Survey of Sweden Research Papers, Ca 81: 241-248.

Påsse, T., Robertsson, A.-M., Miller, U. \& Klingberg, F., 1988. A Late Pleistocene sequence at Margreteberg, southwestern Sweden. Boreas 17: 141-163.

Robertsson, A.-M., 1991. The last interglacial in northernmost Sweden. Quaternary International 10/12: 173-181.

Robertsson, A.-M., 1997. Reinvestigation of the interglacial pollen flora at Leveäniemi, Swedish Lapland. Boreas 26: 81-89.

Robertsson, A.-M. \& Garcia Ambrosiani, K., 1992. The Pleistocene in Sweden - a review of research, 1960-1990. Sveriges Geologiska Undersökning Research Papers Ca 81: 299-306.

Robertsson, A.-M. \& Rodhe, L., 1988. A late Pleistocene sequence at Seitevare, Swedish Lapland. Boreas 17: 501-509.

Robertsson, A.-M., Svedlund, J.-O., Andrén, T. \& Sundh, M., 1997. Pleistocene stratigraphy in the Dellen region, central Sweden. Boreas 26: 237-260.

Saarnisto, M. \& Salonen, V.-P., 1995. Glacial history of Finland. In: Ehlers, J., Kozarski, S. \& Gibbard, P. (eds.): Glacial deposits in north-east Europe. Balkema (Rotterdam/Brookfield): 3-10.

Saarnisto, M., Eriksson, B. \& Hirvas, H., 1999. Tepsankumpu revisited - pollen evidence of stable Eemian climates in Finnish Lapland. Boreas 28: 12-22. 